\title{
AYÂNS IN THE OTTOMAN CYPRUS IN THE SECOND HALF OF THE $18^{\mathrm{TH}}$ CENTURY
}

\author{
NURI ÇEVIKEL*
}

\section{Introduction}

To have a better understanding of the so-called "process of decentralization" seems wise to look briefly at the general situation of the Ottoman Empire in the $18^{\text {th }}$ century and even before.

A social, economic and political crisis started in the last quarter of the $16^{\text {th }}$ century ${ }^{1}$ spread and and became effective in the coming century. It would continue prevail all over the empire in the form of a "decentralization process" 2 in the $18^{\text {th }}$ century, especially in its second term.

- Prof. Dr., Gazimağusa - KKTC, Mersin on Turkey.

1 According to the gencral acceptance, this period of crisis started in the late sixteenth century mainly as a result of the "price revolution" which first appeared and shook the economies in Europe. On the issue, some scholars assert that this economic revolution shook fundamentally the traditional Ottoman administrative and social structures, for the Ottoman rulers of the time had abolished the customs imposed on importation of silver to encourage free trade believing that it would have contributed a lot to the imperial treasury, and thereby, let the chcap European silver flow into the Levantine markets. Halil INALCIK, The Ottoman Empire, the Classical Age, 1300-1600, London 1973, p 137-138; Yaşar YÜCEL Osmanl Ekonomi - Kültür - Uygarlık Tarihine Dair Bir Kaymak: Esar Defteri (1640 tarihli), Ankara, Türk Tarih Kurumu, 1992, p. 8-9; Mchmet ÖZ, Osmanlida "Çözülme" ve Gelenekçi Yorumcularn. İstanbul, Dergâh Yayınları, 1997, p. 37-38.

${ }_{2}^{2}$ For general references on the emergence of the ayâns as a class and their political, administrative and socio-economic roles in the Ottoman history, see Mustafa AKDAČ, Celâli İsyânlan 1550-1603, Ankara, 1963; Türkiye'nin İktisadi ve İçtimai Tarihi, Cilt II (1453-1559), II. Baskı, İstanbul, 1995; Halil İNALCIK, “Adâletnâmeler", Belgeler, II (3-4), (1965), p. 149-145; "Centralization and Decentralization in the Ottoman Administration", in Thomas NAFF and Roger OWEN, (eds.), Studies in Eighteenth Century Islamic History, Vol. II, Edwardsville and Carbondale 1977, p. 27-52; Yaşar YÜCEL., "Osmanlı İmparatorluğu'nda Desantralizasyona Dair Genel Gözlemlcr”, Belleten, 38/152 (1974), p. 657-708; Osmanl Devlet Teskilâtına Dair Kaynaklar, Ankara, 1988; Ömer Lütfi BARKAN, "Türkiye'de Fiyat Hareketleri", Belleten, XXXIV/136 (1970), p. 574-590; "Feodal Düzen ve Osmanlı Timarn", Türkiye İktisat Tarihi Semineri, Metinler - Tartısmalar, 8-10 Haziran 1973, ed. by Osman OKYAR ve H. Ünal NALBANTOĞLU, Ankara, 1973, "Türk-İslâm Toprak Hukuku Tatbikatının Osmanlı İmparatorluğu'nda Nldığı Şckiller", Türkiye'de Toprak Meselesi, Toplu Eserler, I, İstanbul, 1980, p. 151-208; Yücel ÖZKAYA, Osmanlı İmparatorluğu'nda Ayânlık, Ankara, 1994; Mehmet GENÇ, "Osmanlı Maliyesinde Mâlikâne Sistemi”, Türkiye İktisat Tarihi Semineri, Metinler - Tartı̧̧alar, 8-10 Haziran 1973, ed. by. Osman OKYAR ve H. Ünal NALBANTOĞLU, Ankara, 1973; 
The unending wars generally resulted in defeats, changings in the nature and volume of the international trade which was chiefly carried out with the European countries, a rapid increase in population and unemployment, the "price revolution" and the widening of monetary relations in the world economy, emergence of new war technologies that necessitated professional armies and required transformation from the fiscal capitalism to the industrial one etc., were also among the most prominent reasons for that crisis $^{3}$. The then Ottoman statesmen had to invent new means like creating new sources of revenue especially in cash for their central treasury and increase the capacity of the existing ones to meet the rapidly widening imperial expenses.

In order to achieve those aims, besides confiscations of the properties of the well-to-do officials (müsâdere) and devaluation $(\operatorname{tag} s \hat{s} \hat{\zeta})^{4}$, initially the state began to collect almost regularly the taxes of "avârzz", "imdâdiye" and "tekâlif", which had been so far harvested during extraordinary periods like wars'. Secondly, the range of "iltizâm method" was to be expanded at the expense of the "timâr system", or in other words, the state changed the sources of revenue, which mostly belonged to the "timâr system", into "mukâta'as" ${ }^{6}$. This would mean to sell some of the imperial sources of revenue to the men of capital for one or three years.

A third method applied by the Ottoman statesmen to provide enough amount of ready money was "mâlikâne system" ". As a system it was quite

Osmanl Imparatorluğu, Devlet ve Ekonomi, İstanbul, 2000; Özer ERGENÇ, "Osmanlı Klasik Döneminde Eşrâf ve Ayân Üzerine Bazı Bilgiler", Osmanlı Araştrrmalan, III (1982); Ahmet TABAKOĞL.U, Gerileme Dönemine Girerken Osmanlı Maliyesi, İstanbul, 1985; Şevket PAMUK, 100 Soruda Osmanl - Türkiye İktisadi Tarihi 1500-1914, I. Baskı, İstanbul, 1990; Suraiya FAROQHI, Osmanlida Kentler ve Kentliler, II. Baskı, İstanbul, 1994; Yuzo NAGATA, "The Role of $\Lambda$ yans in Regional Development During the pre-Tanzimat Period in Turkey: A Case Study of the Karaosmanoğlu Family", in Studies on the Social and Economic History of the Ottoman Empire, ed. by Yuzo NAGATA, Izmir 1995, p. 119-133; Same author, Muhsin-zâde Mehmed Pasa ve Ayânlık Müessesesi, İzmir, Akadcmi Kitabevi, 1999.

${ }^{3}$ BARKAN 1970, p. 574-590; INALCIK 1973, p. 139; TABAKOĞLU, op cit., p. 235-246; YÜCFL 1988, p. IX; FAROQHI, op cit., p. 2.

${ }^{4}$ YÜCEL 1992, p. 8-11.

${ }^{5}$ PAMUK, op cit., p. 127.

6 "Mukata' $a$ " means a tax source. The state used to fix the geographic boundaries and kind of a mukata'a and the maximum level of the taxes, that would be colleted from it. The Ottoman guilds in the cities, customs of external trade or various taxes of a certain region could constitute a "mukâta'a". Mithat SERTOĞLU, Osmanlı Tarih Lügât, 2. Baskı, İstanbul, Enderun Kitapevi, 1986, p. 229.

${ }^{7}$ GENC, op cit., p.231-283. 
similiar to the "iltizâm method"8. By the system the "mukâta'as") were to be sold not for one or three years, but for life in return for an advance payment (mu'accele) and a yearly sum (mâl). The state's expectation from the application of this method was that the "mâlikâne" owners would have been more willing to protect the Muslim or non-Muslim reayah and improve their "mukâta'as", for they would not have to surrender them to the state after a few years. The fourth arrangement, eshâm system, made by the Ottoman rulers of the period was to divide the "mukâta'as" into very small fragments or shares and sell the annual tax revenues of an each share to the rich persons for life in return for a total advance payment. When a share-holder died, his share had to be returned to the state ${ }^{10}$.

In fact, all of those methods failed to remedy the deterioration of the Ottoman economy. Under the existing developments and the changings in the war technology, the Ottoman "timâr system" rapidly lost its importance and thereby, the number of the timâr-holding sipâhîs (cavalry) reduced and came to be useless ${ }^{11}$. As their quality and effectiveness got lawer, the Yeniçeris enlarged in number due to the enterance of many unqualified people from the Turco-Muslim elements into their class, which had only made the burden of the central Treasury heavier.

Along with that corruption in the military and economic systems, the solidarity of the Ottoman society, too, came to be threatened by a social turmoil named as the "Celâlî movements"12 that were in the nature of brigandages and started and widened rapidly especially in the central Anatolia. The "Celâlı" bands were populated by the unemployed youths (levends or gurbet tâifesi and suhte) and the landless subjects who had to abandon their lands (cifts) ${ }^{13}$ due to the pressure of heavy tax burden imposed by the state and the brigands. After leaving their lands the villagers

"The "mültezims" who bought a source of revenue generally had not been carcful about the living conditions or endurability of the peasants and improvement of the "mukata' $a$ ", which he bought by auction. They tried as possible as to squeeze the real producers in their predetermined periods by imposing extraordinary or illegal taxes (tekalif-i şakka) on them in order to get more than they offered to the state in their limited periods.

${ }^{9}$ For comprehensive works on this subject, see Mustafa CEZAR, Osmanl Tarihinde Levendler, İstanbul, 1965 and Karen BARKEY, Bandits and Bureaucrats-The Ottoman Route to State Centralization, London, Ithaca, 1994.

${ }^{10}$ PAMUK, op cit., p. 131.

"YÜCEL, 1988, p. XIII.

12 Consult AKDAĞ 1963.

13 This incidence was to be called in the Ottoman social history as the "great flight" (büyük kaçgun) and continued until 1610. YÜCEL, op cit., p. XIII-XV. 
began to husbandary around the hillsides and crowded the medreses as students in the cities, or mercenary troops (sekban bölüks)" The "sekbân bölüks" had been organized and armed by the provincial governors with the perm ission of the state to protect the social order against the brigandages. It's interesting enough, many of those governors would revolt against the central administration during the $17^{\text {th }}$ century ${ }^{15}$.

In the destruction of the social solidarity of the Ottomans; i.e., in the dissemination of the Muslim and non-Muslim reayah (perâkende vü ihtilâl / perîşan), in spite of being representatives of the state authority, the oppressor state officials (beylerbeyis, sancakbeyis, kadis and their nâibs, mütesellims or muhassils, voyvodas, mültezims and the other members of the "ehl-i 'orf") were the most responsible ones ${ }^{16}$. For, they had abused their power to commit various malpractices ${ }^{17}$ neglecting the firmans of "adâletnâme" ${ }^{18}$ issued by the Sultans. For instance, they sold their own timars to others by way of "iltizâm", demanded illegally foods, sheeps or something else (yem ve yiyecek / koyun ve kuzu taleb etme) from the people during their unlawful visits (il üzerine devre çıma) through "salma", increased the rates of dues and fines (ziyâde taleb), and imposed extraordinary taxes (tekâlif-i şakka) on them ${ }^{19}$.

Eventually, throughout the $17^{\text {th }}$ century all of these economic, military, demographic, social and political provisions were to force the Ottoman Empire to lose a lot from its central authority both in the capital and provinces. In the next century emerged a new social power, namely the local notables (a'yâns) to fill that gap of authority.

\section{Ayâns in the Ottoman History}

The afore-mentioned political, socio-economic, military and demographic circumstances and provisions which began to appear in the second half of the the sixteenth century, shook essentially the traditional

\footnotetext{
${ }^{14}$ In fact, some of these "sekbans" were the ones whom the very state armed and used in the battles against Austria, Venice and the Iranian Safavids. Justin MCCARTHY, The Ottoman Turks, An Introductory History to 1923, Longman, New York and London 1997, p. 167-172.

${ }^{15}$ Ibid., p. 171-174.

${ }^{16}$ TABAKOĞLU, op cit., p. 223-227.

${ }^{17}$ For many kinds of the commitments of the "ehl-i "orf" consult TABAKOC̆LU, op cit., pp. 226-230)

${ }^{18} \mathrm{Sec}$ INALCIK 1965.

${ }^{19}$ YÜCEL, op cit., p. XIII.
} 
Ottoman regime causing it to degenerate and decline steadily ${ }^{20}$ throughout the $17^{\text {th }}$ century. Although having tried to do their best to meet or get accustomed to the newly emerged challenging predicaments of the period $^{21}$, the then Ottoman governments lost a lot from teir central authority both in the capital and provinces.

Although there was not any social power to fill the gap of authority in the $17^{\text {th }}$ century, beginning from the first decade of the following century ${ }^{22}$ a new social class, a fresh power, namely the local notables (ayâns) appeared and took the control or their share from the authority of the central government ${ }^{23}$ in the imperial provincial organization.

The local dignitaries or ayâns were mostly the retired members of the " askerî" class including the "ulemâ", rich merchants or heads of great and rooted families ${ }^{24}$. In the century the incidence of ayâns was to be transformed by the Ottoman State into an institution. Hereafter the state was able to enjoy the right to appoint or depose the ayâns or fix their rights complying with an order ${ }^{25}$.

As time went on, ayâns would become agents of the state and real representatives of the population living in provinces. They achieved this in two phases; first they seized the control of militia forces created with the support of the state for preventing brigandages. And then, in the second stage, ayâns obtained positions of mültezim, muhassıl, mütesellim and voyvoda, which gave them the right to collect taxes, during the process of enlarging the range of iltizâm method at the expense of the traditional timâr system, and implementation of mâlikâne and eshâm arrangements aimed at escaping general economic crisis, or more correctly, increasing revenues in cash and finding new ones to meet the ever-increasing imperial expenses $^{26}$.

20 iNALCIK 1973, p.47.

${ }^{21}$ For a detailed examination of the means invented by the Ottoman governments to escape the stated period of crisis, consult Linda DARLING, Revenue-Raising and Legitimacy-Tax Collection and Finance Administration in the Ottoman Empire, 1550-1660, Lciden 1996.

22 On the history of the Ottomans in this century Faroqhi claims that in the Ottoman history especially the eighteenth century constitutes a period which was "forgotten" or did not sufficiently attract the attention of the scholars upon itsclf. FAROQHI, op cit., p. 10.

${ }^{23}$ PAMUK, op cit., p. 121-122.

${ }^{24}$ GENC, op cit., p. 251.

${ }^{25}$ KŞS (Kılorns Şer'iye Sicilleri / Court Registers of Cyprus, Archive of General Directorate of Vakifs, Lefkoşa - KKTC, Mersin on Turkey, hereafter KŞS) $21: 8 / 1,9 / 1$.

26 TABAKOĞLU, op cit., p. 224. 
In spite of having enjoyed their assistance in the solution of many problems, beginning from 1750's the Ottoman State would have to struggle against the newly born social power, i.e. ayâns. For, most of the members of this class would not both necessarily feel everytime that they had to prefer the interests of the empire to their own and restrain from committing oppressions on the imperial subjets whom they represented.

As tax collectors (mütesellims, muhassıls etc.) ayâns' frequently witnessed abuses against the state and people were of increasing rates of the prescribed taxes of the reayah (salyâne defterine fazla akçe eklemek), not submitting the collected tax revenues to the relevant office, and raping the subjets of the region where they held as mültezims in different ways in assistance of usurers (murâbâhâcilar) ${ }^{27}$.

The period of the Ottoman-Russian War (1768-1774) constitutes a turning-point in the institutional development of ayânllk in the Ottoman administrative and socio-economic history. During the Russo-Ottoman War (1768-1774) the then Ottoman government used all of its sources on which it rested, and this led to great internal changes in the social, economic and administrative structures of the state. In the years of expedition against Russia the newly emerged local powers realized the first steps of a great development and in the following period were to have their influence felt in all of the state affairs and gain great power.

In this period Muhsin-zâde Mehmed Paşa became Grand-Vizier and continued his policy he adopted during his first Grand-Vizierate (1765) towards ayâns of kazas. Mehmed Paşa established new bridges between the central government and local notables by letting them take part in many imperial missions. While taking part in the imperial activities as state agents the local powers, in other words, ayâns would generally pursue their own interests and thereby, come to be a different sonnce of trouble for the state and society of the time. There was a furious struggle among the notables for the post of ayânlık near before and after the War of 17681774. The local inhabitants would be the element which mostly suffered from the social and administrative turmoil caused by the struggling local notables and unjust governor ${ }^{28}$.

\footnotetext{
${ }^{27}$ ÖZKAYA 1994, p.179-209.

${ }^{28}$ NAGATA 1999, p. 142.
} 
In order to stop the fighting between the influential local notables and protect the reayah from the malpractices and oppressions of the state representatives, the Grand-Vizier of the time Muhsin-zâde Mehmed Paşa to reform the method of recognition of ayânlık (ayânship) by the central government. In one of his edict issued on the subject and sent to every district (kaza) in Anatolia and Rumelia, Mehmed Paşa declared that every ayân, after being elected by the reayah in his own kaza, had to be recognized through a mektûb (letter) sent by the Grand-Vizier. By this reform the Grand-Vizier had aimed to keep local peace under the control of the central power. Nonetheless he was dismissed from the office of Grand Vizierate just before the war and his policy towards ayânlık was left, for the central government wanted to make ayâns support the imperial corps with local soldiers, food and munitions. In 1771 Muhsin-zâde Mehmed Paşa was to be restored to his office again and he would adopt the same policy of recognition of ayânlı. The Grand Vizier requested the loyal ayâns to send food and soldiers for the War of 1768-1774 ${ }^{29}$. Until the end of the war a great number of new ayâns emerged in many parts of Anatolia and Rumelia. After the war leading notables remarkably strengthened their political power and many of them, as ayâns, enjoyed political and social influence by way of supplying food, munitions and local soldiers ${ }^{30}$.

Muhsin-zâde Mehmed Paşa in his first term seriously worked to cope with the severe competition and fighting between ayâns. While doing this, on the one hand he tried to protect ayâns who were loyal to the state and restrained from oppressing the people, on the other hand he was punishing the betrayer and oppressor ones. Thereby, the Grand Vizier Muhsin-zâde Mehmed Paşa was trying to keep the provincial administration under control. But unfortunately, in spite of his great efforts to preserve the imperial authority in provinces active and respectable, instead of coming to an end the ayân fightings would worsen. Eventually the Grand Vizier's policy of ayânlık was to be given up due to the unending strife between ayâns in $1769^{31}$.

The ayâns who strengthened their power and came to be an important state agent before and during the War of 1768-1774 by taking advantages of the opportunities provided by the Grand-Vizier of the time Muhsin-zâde

29) For detalicd information on the war sce Osman Kösc, 1774 Küçük Kaynarca Andlaşmast, Türk Tarih Kurumu Yayınları, Ankara, 2006.

${ }^{30}$ NACATA 1999, p. III, 140-144.

${ }^{31}$ NACATA 1999, p. 50. 
Mehmed Paşa would play a crucial role in the movements for modernization in the Ottoman Empire and the Middle-East in the $19^{\text {th }}$ century $^{32}$.

\section{Ayâns and Eşrâfs of the Ottoman Cyprus}

As it was common in other administrative units of the empire ${ }^{33}$, in the province of Cyprus of the second half of the eighteenth century rulers were the governors called muhassils and müsellims or mütesellims. They were responsible for the collection of the imperial taxes of the Muslim and nonMuslim subjets in Cyprus. They were great mültezims, but not everytime necessarily called "mültezim". They bought their positions from sadrazams by way of auction (iltizâm). These big patrons generally preferred to stay in Istanbul and sold their offices or rights to other "sub-mültezims". The lowranked mültezims were in great number and interested in many petty works of iltizâm. In provinces they constituted an influencive socioeconomic class. This class was populated by local well-to-do dignitaries who bought their offices from great mültezims through auction ${ }^{34}$.

Besides sadrazams, who sold their fief (hass) to muhassıls or müsellims by auction, there were other high-ranked officials or officers, too, like vezirs holding fiefs (zeamets and timârs), some members of military class (ehl-i 'örf), mâlikâne and mukâta'a owners, founders of great pious foundations (vakıf) and their official representatives called voyvodas, mütevellis, câbis $\mathrm{etc}^{35}$. to supply the mentioned class with an another human source. They enjoyed a special place in the Cypriot society. These people of highpositions would generally live in the capital and sell their sources of revenue to the men of capital again by way of iltizâm for afixed period in return for some predetermined payment in advance or by installments.

${ }^{32}$ NAGATA 1999, p. 2.

${ }^{33}$ GENC, op cit., p. 251.

${ }^{34}$ C.D. COBHAM, Excepta Cypria, Materials for a History of Cyprus, Cambridge 1908, p. 351.

${ }^{35}$ For example, "Cerîre-i Kıbrıs'ta vâkî' Ca 'lè Paşa vakfindlan..." A. DVN. KBŞ (Prime Ministry Ottoman Archivc, İstanbul / Turkey, hereafter KBŞ), File / Document No: 1/1 (1150 of I licrah); KBŞ: 1/1, 1150 H.; "Sadr-1 esłâk merhûm 'Abdu'l-lâh Paşazâde Mchmed Sa'î̀ Beg kullarının ber-vechi mâlikâne 'uhdesinde olan Kıbrıs cezîresincle Karpaz Kazâsı'nda Trikomo ve Kumukebîr ve Aftikomo ve Dipkarpaz nâm dört "aded vakf karye..." A.DVN. KBM (Prime Ministry Ottoman Archive, Istanbul/Turkey, hereafter KBM): 1/9, 1179 H.; "Ilaramcyni'şşerifcyn evkâfindan Kıbrıs'ta Gerinc Kazâsı'na tâbî Labıa nâm karyedeki I laydarpaşazâde Mehmed Beg'in evkâfi ve mukâta'ası... " KBM: 1/21, 1191 of Hicrah, and "Sadr-1 'azâm-1 csbâk Coorlulu 'Alî Paşa merhûmun vakf-ı şerîfi mülhakâtından cezîre-i Kıbrıs'da vâkî' Poli nâm çiftliği vakfın mütcvelliyesi 'Alî Paşa'nın akâribinden... " KBM: 1/55, 1202 of Hicrah. 
The latters also would transfer their offices to some other native buyers. Thus, even a kind of hierarchical order was to come into being among the intermediaries called mültezims at the expense of their sources of revenue and the native people living there ${ }^{36}$.

Consequently, in the province of Cyprus, too, the well-to-do and distinguished individuals created a new socio-economic class in the period. They came from the island's society and in time, seized the control of the sources of revenue of the province through iltzâm and other similar fiscal methods. They were to be called, as reflected in the documents, "Kibris . a yân ü eşrâfı" (the dignitaries and the most esteemed of Cyprus).

The ayâns and eşrâfs of Cyprus were the dignitaries of the local population. These people could rarely obtain offices of muhassil or müsellim, but in general their ecinomic and political power sufficed to get the positions of "voyvoda", "mütevelli", "câbî" and "nâ'ib of kadi". They were mostly retired members of the ruling class, ehl-i "örf and "ulemâ, who stayed in Cyprus and made marriages with the native, instead of returning to their birthplaces after their retirements.

The ayâns and eşrâfs of Cyprus had gained great dignity in the rural society through holding an office in many years, and getting rooted by way of marital relations. The titles that were adopted by the ayâns and eşrâfs of Cyprus for themselves or used by others for them, indicate this very clearly: "Miralây-1 sâbık Hacı Mehmed", "Kethüdâ-yı sâbık Hüseyin", "Ağa-yı Yeniçeriyân-ı sâbık" veya "Sâbıkan Kıbrıs Defterdârı Es-scyyîd İsmail Efendi" ${ }^{37}$.

The Ottoman documents of the period reveal that the representatives and dignitaries of the non-Muslim reayah (zimmî) could also become from ayân and eşrâf in Cyprus like "sâbık (former) Rum Tercümânı" and "Tuzlalı sâbık Kocabaş"; in other words, there were mültezims among the zimmî subjets ${ }^{38}$. As mültezims, the Christian notables were able to have

${ }^{36} \mathrm{~A}$ quotation from a document of KBM: 1/8, 1179 of I licrah, indicates this hicrarchy:

Sadr-1 sâbık merhûm Nbdu'l-lâh Paşấnın âsitânede sâkin sağîr oğlı Mehmed Sa'îd $13 \mathrm{eg}$ 'uhdesinde olan Kıbrıs cerîresinde Karpâz kazâsında Trikomo ve Kûmûkebîr ve Afitukomo ve Dîpkarpâz. nâm dört 'aded vakıf kurâları mûmâ-ileyhin umûr-u husûslarını rü'yct iden Haremkethüdâsı 'Albdu'l-lâh Ağâ nâm kimesne tama'-1 hâma teb'ıyyct ile yetmiş üç senesinden berü tarafindan karyclerimizi iltizâm cylediği kendi adamîsi [adamı] olan cl-hâc 'Alî $\Lambda$ ğâ nâm kimesne altu seneden berü...

${ }^{37} \mathrm{KBS}: 1 / 5,12,14,16,54,58 ; \mathrm{KBM}: 1 / 4,14$.

${ }^{38} \mathrm{KBM}: 1 / 14,39$. 
many great farms (çiftliks) and the right to collect imperial taxes (emvâl-i mîrî) of the regions including non-Muslim population ${ }^{39}$.

Ayâns and eşrâfs of Cyprus who were mostly the retired members of the ruling elite ('askerî and 'ulemâ) in the period of 1750-1800 A.D. emerged as a real new and effective socio-economic class and power through their influence and authoruties both in Cyprus and the capital, İstanbul. They rised to such a position by means of their wealth, they gained during their long term of office in the province and close relations like marriages they established with native people. In this period the incidence of ayâns and eşrâfs seems to have completed the process of turning into an institution.

Among the existent documents of the period there is a very characteristic one, an imperial paper (hatt-1 hümâyûn) registered in onc of the sicills (court registers) of 17 Şevvâl 1198 H. / 24 Aughust 1784 A.D ${ }^{40}$. The document provides us with explanatory information like nature and development of the matter of ayâns and eşrâfs both in the empire and the province; i.e. their social origins, their appointmens and depositions, their responsibilities, interclass relations, their abuses and measures to be taken against their malpractices.

As it is understood, the document was written to all vezirs, commanders, governors, judges and their helping personnels, fief holders and the ayâns of the imperial administrative units: “...Anadolının sağ kolı yemîn ve yesâriyle nihâyetine varınca vâkî'..." olan "vüzerâ-yı 'azâm .... ümerâi'lkirâm .... mîr-i mîrân-1 kirâm .... mevâlî-yi fihâm .... sâ'ir kuzât ve nüvvâb ve bi'l-cümle zâbitân ve a yân-ı memleket". This imperial order was released and sent to the island by the sadrazam of the time through one of his personnels (çukadâr), el-Hac Ebubekir. This "suret-i hatt-ı hümâyûn" orders the ayâns that the regulations, which were previously set up by a firmân (imperial paper) of 1193 .H. / 1779 A.D. for the matter of distortions come across, had been disobeyed, and such kind of commitments had had to be avoided.

Through a general examination of the document of 1198 of Hijrah one can reach at such results: First of all, the issue of ayâns became one of the most important administrative and socio-economic matters of the empire in the second half of the eighteenth century.

\footnotetext{
${ }^{39} \mathrm{KBM}: 1 / 4 ; \Lambda$. DVN. KBE (Prime Ministry Ottoman Archive, İstanbul / Turkey, hereafter KBE): 20559-20560.

${ }^{40} \mathrm{KSSS} 21: 8 / 1,9 / 1$.
} 
The document, moreover, shows that the incidence of ayâns had exactly transformed into an institution in the Ottoman Empire during the period under examination. According to the firmân of 1198 of Hijrah, a firmân was issued about "ayânlık maddesi"; i.e. matter of ayâns' office in 1193 of Hijrah, which abolished the existing applicaiton and established new principles of who and how could be an ayân ${ }^{41}$. The firmân of 1193 of Hijrah ordered that the appointment of ayân in the imperial territories (memâlik-i mahrûse) would not be realized any longer by papers released by sadrazams and governors (emr-i 'âlî ve vâlî buyruldısı) as it was usual in the past. Since 1193 of Hijrah governors and judges would not issue buyruld $^{42}$ and mürâsele ${ }^{43}$ for anybody who wants to be ayân.

Instead of the previous application mentioned above, the firmân of 1193 of Hijrah produced a new regulation according to which people of every sub-district (kazâ) and region (belde) had to present petition (istidâ') for appointment of a person whom they saw that he had sufficient qualifications (mehâsin-i etvâr) and thereby, chose him as ayân. After throughly examining whether the candidate, who was chosen and petitioned by the reayah, was suitable for the ayânship, judges (kadis) would notify the situation to the Sublime Porte by a written judicial decree (i'lâm). After that, the Sublime Porte was to issue a permission letter (izin mektûbı) and give it to the proposed nominee after taking an exact decision on him. Thereafter, it would not be possible to choose and appoint ayân in any way except for the new arrangement.

In short, by the regulation of 1193 of Hijrah the right of governors to nominate anyone for ayânship was annulled and initiative was given to the people. This was, indeed, a kind of radical reform in the provincial administration in favour of the ruled. Hereafter, the imperial subjets of the Province of Cyprus could select their own ayâns.

Nonetheless, as the firmân of 1198 of Hijrah reveals again, from 1193 of Hijrah, various malpractices on the newly built system began to be reported to the Sublime Porte. For instance, some governors had dared to install ayân (a'yân nasbına cür'et) without waiting for permission letter of

${ }^{41}$ KŞS 21: 8/1.

42 "Nomination paper for a lower official", New Redhouse Turkish-English Dictionary, $11^{\text {th }}$ Ed., Istanbul, 1990, p. 204.

${ }^{43}$ “ $\Lambda$ judgc's lettcr of appointment". Ibid., p. 825. 
sadrazam and continue collecting money (akçe) from the people under the name of "a "yâniyye" just like the other officially prescribed taxes.

As a matter of fact that there were very different malpractices committed by the governors on the issue of ayâns, but one of them was a quite distinctive example; at the time of passing the rule of a province (eyâlet) or district (sancak) from one to another on necessity, every new governor used to appoint or depose ayâns (a'yân 'azl u nasbı) very frequently by neglecting the firmân of 1193 of Hijrah in order to levy money on people. Thus, the most oppressed ones would be the poor reayah (fukarâ ve zu'afâ) as usual.

Then, in order to avoid the mentioned oppressions of the governors, the Ottoman central government of the time had to issue the firmân of 1198 of $\mathrm{Hijrah}^{44}$. By this firmân, the importance of obediance to the regulations set up in 1993 of Hijrah was underlined and the relevant provincial rulers were strongly warned by recalling them their responsibility once more.

By the firmân of 1198 of Hijrah the Sublime Porte also banned the governors from collecting money openly or secretly from people under the name of "expenses of sending petition and written judicial decrees to İstanbul" (a'yânlık 'arzı mesârifi ve i'lâm harcı), and notified that those who would dare to go on the same way were to be soon liquidated whereever they were found disregarding whoever they were (her kim olur ise bi-lâ imhâl haklarından geleceğim muhakkak olmağın).

Additionally, in the same document it was also stressed that those oppressors who claimed for ayânship (a'yânlık iddi'â iden zalemeler) with the help of governors and judges in provinces were frequently struggling among themselves for their own sake ${ }^{45}$ and extracting from the poor (fukarâ) the sums they paid to governors, and thus, the tax-paying subjects of the empire were becoming the most squeezed and disturbed, and the İstanbul government was aware of these happenings.

${ }^{44}$ KŞS $21: 8 / 1$.

45 The situation was not different in the Ottoman Karaferye (Veroia in (ireek) in the district (sancak) of Salonika in the period. Antonis ANASTASOPOULOS, "Lighting the Flame of Disorder: Ayan Infighting and State Intervention in Ottoman Karaferye, 1758-59", International Journal of Turkish Studies, 8 (Spring 2002), p. 73-88. 
The "Hatt-1 Hümâyûn" of 1198 of Hijrah, registered in the sicill ${ }^{46}$, provides us with further materials on implementation of the new procedure established by the firmân of 1193 of Hijrah for proper appointment of ayâns in the regions. For instance, the election of an ayân by the people for supervision of their own issues, preparation of a round robin ('umûmî ve ittifâkî 'arz u mahzar) describing qualifications of the person elected for ayânship, and submission of this petition by the judge (kadi) to the capital in the form of a judicial writing (inhâ) were to be obligatory, but not enough for completion of the process.

The candidates for ayânship had not to be accepted as appointed if they claimed that they were elected by the people (memleketlü) and notified to the Sublime Porte, unless permission letter (izin mektûbı) of sadrazam was received.

From the firmân of 1198 of $\mathrm{Hijrah}^{47}$ one can also learn the way to solve the problem emerged when the people of a region or district did not agree on one of the candidates for ayân's office. The document explains that in such a case, among the people of the region another person who was to be convenient (âher münâsib); i.e., to be expected to have good conduct (husn-i hâl), and to have served to the people and enjoyed capability of supervising the affairs of the province, was to be determined and installed by the sadrazam's office. Finally, by governor and judge he would be given a letter (kâ'ime ve mektûb) providing permission and licence (izin ve ruhsat).

The firmân under examination continues to make further contribution to the subject matter by revealing that in any way nobody could be rised to ayân's office except for the way defined above, and the regularly fixed ayâns should not have been deposed by governors for any personal purposes of greed. Otherwise, those who had enough courage to commit such a malpractice were to be punished in the heaviest way. And then, the man who unlawfully claimed for ayânship, or the properly fixed ayâns who desired to extract money from the people through adding sum to the notebook (defter-i tevzî́a) kept for allocation of tax burden of the people under the name of "a "yâniyye" by saying that they had paid akçes to governors and judges and spent a lot of money had to be immediately

\footnotetext{
${ }^{46}$ KŞS $21: 8 / 1$.

47 The transliteration of this very characteristic and explanatory firmân from Arabic to Latin alphabet is appended to this work.
} 
reported to Istanbul where this kind of ayâns (a'yân makûleleri) whose commitments were fixed would be punished in the most suitable way ${ }^{48}$.

Towards the final section of the document, there are noticable points. First of all, it reminds the local authorities (governors and judges) that ayân appointments were merely for the protection of the subjects (himâyet-i ra'iyyet); therefore, any member of the military class like serdârs etc. could not interfere in that issue. If they insisted unnecessarily on appointments or depositions of ayâns, governors and judges had to notify them to their units (ocaks), and have them banned from these actions by means of their commanders. And then, after having made governors and judges remember to care for keeping the order of fixed ayânship in effect everywhere, the Ottoman central government reminded ayâns their duties and the things which they had to take into consideration, wanted them to comply with the principles, that were set up by the firman of 1193 of Hijrah, in their deeds and positions, and restrain from oppression or causing to any abuses.

Final sentences of the firmân of 1198 of Hicrah $^{49}$ make a special emphasis on the frequently committed malpractices of ayâns in collecting prescribed money and dues from the people for their own expenses. As it was noted in the document, ayâns had the right to collect a certain amount of money for their usual expenses they made in supervising the affairs of the people, and but in this process some of them used to rape the reayah by increasing in the "defter of distribution" the amount of money to be collected from the inhabitants of the region, and send the copy of the defter including distorted figures to İstanbul.

In addition to the document examined in detail above and shedding light on the the general position of ayâns in the empire, there are other archival materials witnessing how the incedence of ayâns took place in the Province of Cyprus.

As much as these documents reveal, especially in the second term of the eighteenth century the local dignitaries, "ayâns and eşrâfs of Cyprus", were to fill the gap of authority emerged remarkably in provinces as a result of various abuses committed by officials, the very representatives of the state's power.

\footnotetext{
${ }^{48}$ KŞS $21: 9 / 1$.

49 Ibid.
} 
In time, ayâns and eşrâfs of Cyprus would rise to such a position that the state was to necessarily accept them as agents and seek their help in solution of many local problems, for they captured sometimes offices of muhassil, mütesellim, but usually the positions of sub-mültezim, rights for supervision of many administrative and municipal affairs, and jobs of public security and defence of the island's shores against piracies or other outsiders' challenges. The fact that the titles of the local administrative judicial and military elite and that of the ayâns and eşrâfs of the province were cited together in the inscriptio part (elkâb) of firmâns and other official papers issued by the Ottoman goverment in the period ${ }^{50}$ for the affairs mentioned above also indicates it very clearly: "'Umûmen 'ulemâ ve sülehâ ve e'imme ve hutebâ ve zu'emâ ve Ģorbactyân ve sâ'ir a'yân ü eşrâf...." or:

"Lefkoşa Nâ'ibine ve Eyâlet-i Kıbris'da vâki' kazâlarnn kuzât ve nüvvâbına ve Kibris Muhassılı zîde mecduhuya ve zikrolunan kazâlarn a'yân ve zâbitân ve vücûh-ı memleket ${ }^{51}$ ve bil'-cümle is erlerine hüküm ki....".

Although having spent great efforts in carrying out a lot of jobs for the sake of the state until 1750's as state agents, it was also seen that in 1750's1800 A.D. the ayâns and eşrâfs of Cyprus were to lead (hilâf-1 kânûn ve defter / şer“ ve kânûnâ muğâyir) the subjects of the province to be oppressed and disseminated (perâkende vü perişân) by way of abusing their authorities (zulm ü te'addî), which they obtained through getting offices of muhassıl, mütesellim, mültezim, mütevelli, voyvoda, câbî, or kadi nâib etc. by auction (iltzâm) ${ }^{52}$. For, selling a source of revenue for a fixed period or for life (ber-vech-i mâlikâne $e^{53} /$ eshâm $^{54}$ ) was essential in the method of iltizâm. Hence, there was no principle that morality of buyers also had to be definitely regarded. The mültezims, too, were to extract money from the people more then they paid in advance to their big patrons in their tenures. They would not sufficiently take into consideration the conditions of their source of revenue and villagers living in them. They had openly disregarded laws and related regulations. A relevant document of 25. 12. 1191 of $\mathrm{Hijrah}^{55}$ indicates this:

\footnotetext{
${ }^{50} \mathrm{KBM}: 1 / 22-23,28,40,53$; KBŞ: $1 / 5,8,35$.

51 This title also means dignitaries of a place.

52 KSुS $21: 8 / 1$.

${ }^{53} \mathrm{KBM}: 1 / 9$.

${ }^{54} \mathrm{KBM}: 1 / 50$.

${ }^{55} \mathrm{KBS}: 1 / 17$.
} 
"Kıbrıs cezîresinde medîne-i Tuzla kazâsına muzâfe Arpera nâm karyede vâkî‘ mülkiyet üzre mutasarrıf olduğum çiftlik ve bağçe derûnında mevcûd devâbb ü mevâşî ve sâ'ir eşyâsı bedel-i mahsûl-i ma'lûme ile bundan akdem 'Abdü'l-bâkî Ağâ iltizâmında iken birkaç sene mukaddem mûmâ-ileyh iltizâmdan fekk ve ma'rifet-i şer'le ber-vech-i meşrûh çiftlik-i merkûm ve bağçe-i mezkûrın mevcûdı olan tohumlık ecnâs-1 hayvânât ve devâbb vü mevâŝi ve sâ'ir eşyâsı tahrîr ve ber-mûceb-i defter müste'cir-i âher 'uhdesine iltizâm ve eşyâ-yı mezbûre yedine teslîm ve ol dahî tefevvüz ü tesellüm eyleyüb lâkin bu vakte değin imârlarnnda tekâsülden mấadâ ebniyelerinin harâbiyetine ve tesellümî olan eşyânin itlâf ve izâ'atına bâdî olduğına binâ'en müste'cir-i merkûmın dahî 'uhde-i iltizâmından fekk ve âhere iltizâmı iktizâ eylemeğin..."

The most frequently witnessed oppressions of the ayâns and eşrâfs of Cyprus were of making illegal inspection visits through the region (il üzerine devre çımak), hearings judicial cases in unprescribed places (icrâ-i ahkâm-ı şer"iyye), in the meantime demanding provisions without making any payment (yem ve yiyecek taleb itme), increasing the rates of taxes (kânûndan ziyâde akçe / penbe ve ipek almak / taleb itmek), imposing on the people illegal taxes like şartlama, teşrifiyye, kudûmiyye, mübâşiriyye, zâhire-bahâ, sarây döşemesi, tekâlif-i şâkka etc., usurpation of others' properties (fuzûlî zabt) and taking bribes ${ }^{56}$.

In the socio-economic discontent and upheaval of the period, role of the ayâns and eşrâfs of Cyprus was quite effective. Under an inflationist condition, the ayâns of Cyprus, who seemed morally corrupt, just after having bought the right to collect taxes of a source of revenue by auction, were to make the highest profit by squeezing mercilessly both the source of revenue and the people living in their regions at any cost. One of them was Muhassıl of Cyprus Çil Osman (Silahşör). He took the position of muhassillık in 1178 of Hicrah (1764/65 A.D.). Yuzo Nagata who studied the ayânlık issue of this period in detail defines Çil Osman Ağa as the worst of the muhassils ${ }^{57}$. He was killed together with some of his men by the Muslim - non-Muslim people of Lefkoşa (Nicosia) in an incident because of the fact that he tried to collect imperial taxes from the reayah at a level more than prescribed. In the same incident Çil Osman's residence (Saray) and properties were looted, as well.

${ }^{56}$ KBSS: 1/12, 15, 20, 26, 39, 42-43, 45-46, 49, 54; KBM: 1/8, 15, 21.

${ }^{57}$ NAGATA 1999, p. 28. 
Dizdar Halil's revolt (1765) witnessed in this period was another remarkable development that should be cited here ${ }^{58}$. Following the turmoil the Ottoman central government had wanted a certain amount of compensation from the reayah of Cyprus in return for the looted properties of the murdered muhassıl Çil Osman Ağa. Although the Christians accepted to pay the ordered amount of money (guruş), the Turks opposed to make any payment claiming that they did not have any interest in the issue. They revolted against the local Turkish government under the leadership of Dizdar Halil, Commander of Girne Castle. Dizdar Halil made Değirmenlik (Kythrea) a sub-district (nahiye) of Lefkoşa center for their movement and urged that he was installed as muhassll of Cyprus by the Ottoman government ${ }^{59}$. It is understood from the documents that Dizdar Halil as pseudo Muhassil of Cyprus collected taxes from the reayah of the island ${ }^{60}$.

The Grand Vizier Muhsin-zâde Mehmed Paşa who came to office instead of Bâhir Mustafa Paşa in 1765 to be his second term, had ordered Muhassil Hafiz Mehmed Efendi to restore the order and collect the necessary compensation from the reayah. Then the Grand Vizier ordered the new Muhassil of Cyprus Süleyman Efendi to have Dizdar Halil and his friends executed.

After coming of auxiliary troops from Anatolia under the command of Kaptan Malikî Hacı Mehmed, Kaptan Cafer Bey and the Ayan of Silifke Güllü-oğlu Mustafa the upheaval was suppressed, Dizdar Halil was hanged in the Fortress of Girne and his cut off head was sent to Istanbul ${ }^{(3)}$.

One more characteristic example for the oppressor muhassils of the period was El-hâc "Alî. He was a mültezim. According to a round robin of 1179 H. / 1765 A.D., ${ }^{62}$ six years ago $^{63}$ he bought a source of revenue (mukâta'a) in the sub-district (kazâ) of Karpas by auction from Kethüdâ of Harem 'Abdullah Ağâ who was deputized by Mehmed Said Bey, the younger son of the late former Sadrazam Abdullah Paşa. Some inhabitants

\footnotetext{
${ }^{58}$ For detailed documentary information about Çil Osman and Dizdar Halil incidents see Nuri Cevikel,

${ }^{59}$ Mühimme Defteri, no: 165, p. 3. Referred in NAGATA 1999, p. 31.

60 Halil Inalcık, "Kıbrıs'ı Türk İdaresi Altında Nüfus", Kıbris ve Türkler, (Ed. Cevat (Gürsoy), Ankara, 1964, p. 37

${ }^{61}$ NAGATA 1999, p. 33.

${ }^{62} \mathrm{KBS}: 1 / 8$.

${ }^{63}$ Means 1173 of Hicrah.
} 
of the sub-district of Karpas who were no longer able to bear the burden of the maltreatments of the mültezim El-hâc 'Alî requested from the Sublime Port a firmân ordering deposition and replacement of the mültezim with a new, just, cherishing his subjets and pious one (...emr ü fermânları ile bir ehl-i insâf ve ra'iyyet-perver ve mütedeyyin bir kimesneye iltizâm....).

The same document shows another fact that besides the abuses they committed as mültezims during their tenure, the ayâns and eşrâfs of Cyprus had also tried to prevent their oppressions to be heard in Istanbul by avoiding the people to leave their districts or sub-districts and the island for taking their complaints to the capital of the empire. The documents reads:

"İsm-i mâl ıtlâk olunur nesnemiz kalmayub ve ehl ü 'yyâl-i evlâdlarımıza ta'arruz ile 'rrzlarımız pâ-yi mâl ve beyne'n-nâs rüsvây vü bed-nâm kaldıklarımızdan birkaç def'a mahallinde Kıbrıs muhassıllarına mezbûrlardan iştikâ murâd eylediglerimizde a yândan mezbûrın mu'îni ve hâmîsi el-hâc 'Abdu'l-bâkî Ağâ bizleri zecrenle [zecrile] tahvîf ve men'-i ekîd ile iştikâdan men' ve der-'aliyyeye gelüb isstikâ itmek murâd eylediğimizde bir ferdi karyelerimizden taşra salıvirmeyüb bu defa da dört 'aded karye re'âyâları fukarâları der-'aliyyeye irsâl içün bu dört nefer kullarını intihâb ve cümle taraflarından vekâlet ile ve Rûmî mektûblarıyla ber-takrîb 'Arabistân yakasına geçüb bir neferimiz esnây-1 tarîkda hasta kalub bu üç nefer kulları vekâletligimiz ile der-'aliyyeye gelüb mektûblarımızı Harem-kethüdâsı 'Abdullah Ağâ'ya ibrâz eylediğimizde..."

In spite of the obstacles of every kind put in front of them by the ayâns and eşrâfs of Cyprus from time to time the Ottoman subjects of the province achieved to have their complaints to be heard by the central government. On having reports about the oppressions of the local powers on the tax-paying subjects in Cyprus the Ottoman government of the time did not restrain from struggling furiously against the oppressors ${ }^{64}$. In this context, for instance, Muhassıl (governor) El-hâc 'Abdulbâki Ağâ one of that kind men, was deposed and exiled in 1785 A.D. to Yafa of Palastine depending on te report came from Cyprus and verified the complaint of the Muslim and non-Muslim reayah ${ }^{65}$ about the muhassil.

\footnotetext{
${ }^{64}$ The then Ottoman government also acted in the same manner against the oppressor ayâns in the other parts of the empire. ANASTASOPOULOS, op cit., p. 75.

${ }^{65} \mathrm{KBM}: 1 / 40$; KBŞ: $1 / 29,31$; СOBHAM, op cil., p. 368.
} 
In another case, again on the accusation of the Muslims and nonMuslims of Cyprus a special inspector was sent to the province in 1786 A.D. He prepared a report and sent it to the capital. Depending on the report Muhassıl (governor) 'Alî Ağâ was removed from his office and confined to the fortress of Mağusa, to be a deterrent to others ('ibreten li's-sâ'ire)

And then, both as a member of representatives of zimmî reayah and Interpreter of Governor's Court (Kıbrıs Dîvân / Muhassıl Tercümânı) Aci Yorgaki veled-i (son of)Yanni was arrested and sent to İstanbul to be put on trial as a result of being accused of making injustices about the amount and allocation of the zimmîs' tax burden (hilâf-1 şer" vergileri hususunda zulm ü te'addî itmek) and usurpating the right of inheritance of a zimmî (hakk-1 'irsiyyesini fuzûlî zabt itmek) ${ }^{67}$

\section{Conclusion}

Under the influence of new political, social and economic predicaments the Ottoman Empire had come into a period of crisis in the last quarter of the sixteenth century. The new challenging problems of the period shook the traditional Ottoman regime. Although having spent great efforts to escape the crisis, the Ottoman rulers failed to give an end to the deterioration and rapid decline of the state. So, by the end of the $17^{\text {th }}$ century the Ottoman State had considerably lost its authority both in the capital and provinces.

The lack of authority caused a new local socio-economic class to appeare in the Ottoman provinces from the beginning of the $18^{\text {th }}$ century onwards. The members of this class were the notables, namely the ayâns of the regions. They were generally retired state officials and officers, the rich merchants and the heads of great rooted families. They got rapidly the control in the Ottoman provincial organization through seizing the important offices and positions of mültezim, muhassıl, mütesellim, mütevelli, voyvoda, câbi, nâibs of kadi etc. by way of auction (iltizâm). Thereby, they became both collectors of the imperial taxes of the reayah and governors of the provinces. The ayâns had their influence felt strongly and widely in the empire in 1750-1800. Meanwhile, a new regional social and economic power called the "ayâns and eşrâfs of Cyprus", too, was to come into view in the Province of Cyprus.

\footnotetext{
KB6 $\mathrm{KBM}: 1 / 44,50-51$.

${ }^{67} \mathrm{KBS}: 1 / 25,29,31$.
} 
In the period, the Muslim and non-Muslim dignitaries of Cyprus populated the newly emerged class, and the incidence of ayâns transformed into an institution with the help of the state. In the province, the members of this class once had made great service to the state and society. Their assistance had been sought by the then Ottoman central governments in carrying out their many duties like some military services, collecting taxes, keeping social order, etc.

Nonetheless, some of the ayâns and eşrâfs of Cyprus selfishly began to act at the expense of the state and the reayah of the province during the period. They changed into a group of bandits against which the state inevitably had to fight. For, they would usually prefer their own interests to the State's. So, they had comitted various malpractices and injustices to the ruled in the province.

The then Ottoman statesmen tried to protect the tax-paying Muslim and non-Muslim reayah from the oppressions of the ayâns and eşrâfs of Cyprus by doing their best. To achieve this aim, on the one hand, they punished severely those who caused the local population to be squeezed and disseminated, and on the other hand, they realized a reform in the method of appointment and deposition of ayâns through transferring the initiative in the election of ayâns from governors and judges to the people of the province. But, in spite of these measures, the relevant documents of the period examined in this study reflect clearly that the struggle between the oppressor ayâns and the state lasted until the end of the eighteenth century. 
APPENDIX: The firmân of 17 Şevvâl 1198 of Hicrah registered in the KŞS (Court Register of Cyprus): 21 : 8/1 - 9/1.

\section{Mu'cebince 'amel olına}

\section{Sûret-i hatt-1 hümâyûn}

Düstûrûn-1 mukrimûn-1 müşînû-ı mefhûmûn-1 nizâmi'l-âlem müdebbirûn ve umûri'l-cumhûr bi'l-fikri's-sâkıb mütemmimû mehâmmi'lenâm bi'r-re'yi's-sâ'ib mümehhedû bünyâni'd-devleti ve'l-ikbâl müşeyyedû erkâni's-sa'âdeti ve'l-iclâli'l-mahfû kaviyyi bi-sınûf-i 'avâtıfi'l-meliki'l-a'lâ Anadolının sağ kolı yemîn ve yesârıyle nihâyetine varınca vâkî' olan vüzerâyı 'azâm edâma'l-lâhu te'âlâ iclâluhüm ve e'âzım-i'l-ümerâi'l-kirâm efâhimi'l-küberâ'i'l-fihâm ulü'l-kadri ve'l-ihtirâm eshâbi'l-ferdi'l-ihtişâmi'lmuhtassûn bi-mezîd 'inâyeti'l-meliki'l- a'lâ mîr-i mîrân-1 kirâm dâme ikbâluhüm ve akzâ'l-kuzâti'l-muslimîn evlâ vülâti'l-muvahhidîn mu'âdili'lfezâ'ili ve'l-yakîn râfi'û i'lâmi'ş-şerî'ati ve'd-dîn vârisû 'ulûmi'l-enbiyâ'i ve'lmürselîni'l-muhtassûn bi-mezîd 'inâyeti'l-meliki'l-mu'în mevâlî-yi fihâm zîdet fezâ'iluhüm ve mefâhiri'l-kuzâti ve'l-hükkâm mu'âdili'l-fezâ'ili ve'lkelâm ve sâ'ir kuzât ve nüvvâb zîde fazluhüm ve mefâhiri'l-emâsili ve'lakrân bi'l-cümle zâbitân ve $a^{\boldsymbol{c}} y a ̂ n-\imath$ memâlik zîde kadruhüm tevkî'-i refí'-i

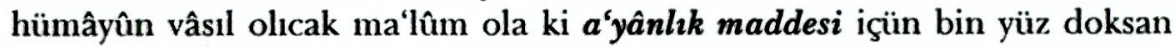
üç [1193] senesinde hatt-1 hümâyûn-1 şevket-makrûnımla mu'anven muhâyâ-yı efzâ-yı (?) sudûr olan evâmir-i 'aliyyem mazmûn-ı münîfi muktezâsınca memâlik-i mahrûsemde vâkî' büldân ve kazâlarda $a^{c} y a ̂ n$ nasbı emr-i 'âlî ve vâlî buyruldısıyla olmayub vülât ve hükkâm taraflarından fîmâba'd $a^{\prime} y a ̂ n l ı k$ içün buyruldı ve mürâsele virilmeyüb bir kazânın 'umûm üzre re'âyâsının a'yân nasbı istidâ' eyledikleri kimesnenin mehâsin-i etvârı 'indlerinde müsellem ve ma'rûf olduğına tahsîl ü vukûf ve ıttılâ' olındıkdan sonra hasbîce keyfiyyet-i hâli sadr-1 a'zam tarafina i'lâm ve sadr-1 a'zam tarafindan dahî ol kimesnenin hâline 'ilm-i yakîn hâsıl oldıkda izîn mektûbı tahrîr olmak ve bundan gayri tarîk ile a yânlık olınmamak husûsları münderic ve mestûr iken bu nizâma mugayir vâlîler taraflarından bi-lâ mektûb-1 sadr-1 a'zamî $a^{\prime} y a ̂ n$ nasbına cür'et ve $a^{\prime}$ yâniyye nâmiyle her kazâdan mesârif-i mu'tâd misüllü akçe tahsîlini ve bu vechile münâfí-i 'adet eyledikleri ve bir eyâlet veyahud bir sancâk hasbe'l-iktizâ bir senede bir iki

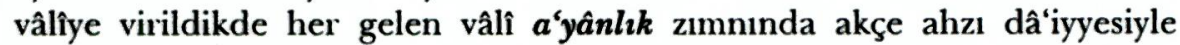
a'yân 'azl u nasbına hilâf-ı fermân-ı hümâyûn buyruldı ve hal' ve ekâsir misüllü harekât-i zâlimâneye cesâret eyledikleri tahakkuk-gerde-i şâhânem olub fukarâ ve zu'afâya böyle zulm ü te'addî olındığına kat'â rizâ-yı 
pâdişâhânem olmadiğına binâ'en fîmâ-ba'd bi'l-izn ve mektûb-ı sadr-ı a'zamî a'yân nasbına kangı vâlî ve kangı kazî ve nâ'ib cesâret ve der'aliyyeme a'yânlık 'arzı mesârifi ve i'lâm harcı nâmı ve nâm-ı âher ile ve'lhâsıl a'yânlığı vesîle ile sırrân ve 'alâniyyeten fukarâdan bir akçe ve bir habbe mutâlebe ve tahsîl ile tahrîb-i fukarâ-yı ra'iyyet mûcibe-i sû'-i hareket ider ise cesâret idenlerin her kim olur ise bi-lâ imhâl haklarından geleceğim muhakkak olmağın emr-i şerîfim ısdâr ve sadr-ı a'zam çukadârlarından kıdvetü'l-emâsil ve'l-akrân El-hâc Ebubekir ile irsâl olınmışdır imdi vâlîlerin ve hâkimlerin hilâf-ı evâmir-i şerîfe i'ânetlerile $a^{\text {' } y a ̂ n l \imath k}$ iddi'â iden zalemenin zulm ü te'addîlerinden ve birbirlerine nefsâniyyetlerinden vilâyetlerde münâza'ât-ı maktú'a tehaddüs eylediği ve aralıkda ehl-i 'rz ve re'âyâ pâ-yi mâl oldığı âşikâr ve a'yân olmak içün vâlîlere virdikleri mebâliği fukarâdan aldıkları be-dîdâr olmağla ba'de-izin memâlik-i mahrûsemde kâffe-i büldân ve emsârın fettân ve sükkânı umûrlarını idâreye her kimi $\boldsymbol{a}^{\text {cyân }}$ ittihâz iderler ise 'umûmî ve ittifâkî 'arz u mahzarlar ile ol eşhâsın ve sîret ve ahvâli ve a'yânlığa ehliyet ve istihkâkı der-'aliyyeme inhâ olmak ve bu vechile inhâ olınan şahıslar hem'ân der'aliyyeye inhâ ile $a^{c} y a ̂ n$ olmış olmayub ve memleketlü ihtiyâr ve i'lâm olınmışlar deyü defaten i'tibâr olınmayub sadr-1 a'zam tarafından tahkîk olınmak veyahud $a^{\prime} y \hat{a} n$ intihâbında ahâlî-yi kazâ müttefik olmayub iki taraf olarak bir tarafı birini bir taraf diğer âherini ihtiyâr iderler ise ahad-1 hümâdan birinin hüsn-i hâli(ni) tahkîk ile tercîhî veyahud ahâlî ve hâricden ahâlî-yi vilâyete hayrı ve umûr-ı kazâyı rü'yeti iktidârı olan âher münâsib kimesnenin a'yânlığa intihâb ve ta'yîni sadr-1 a'zamın re'yi ile olub izn ve ruhsatı hâvî $\boldsymbol{a}^{\boldsymbol{y}}$ yân olacak âdemin yedine velâ-yı vilâyete veyahud hâkim-i memlekete hitâben ve kâ'ime ve mektûb virilmek ve bu vechile [KŞS 21: 8/1 / 9/1] sadr-1 a'zam tarafindan sened virilmeksizin bir mahalde ve bir vakitde $a^{\prime} y \hat{a} n$ nasb olınmayub ve bu vechile nasb olınan $a^{\boldsymbol{c}} y \hat{a} n$ tama'a ve hilâf-1 inhâya mebnî 'azl olınmamak ve bu zâbıtanın hilâfı hareket idenlerin eynemâ-kâne eşedd-i 'ukûbet ile cezâları icrâ kılınmak ehass murâd-ı şâhânem idügi sen ki vüzerâ-yı müşâr ve ve mîr-i mîrân ve mevlânâ ve sâ'ir mûmâileyhimsiz ma'lûm oldıkda müfâd-ı hükm-i ita'ât-mehbetini sicillâta sebt ve bundan böyle hilâf-ı hareket olınması maddesi taht-ı zâbıtaya idhâl ve mefhûm-1 emr-i şerîfim ilâ-mâşâ'allâh-i te'âlâ destûri'l-'amel dutılmasına ihtimâm ü dikkat ve eger ben vâlîden hil'at giydim ve yedime vâlî buyruldısı aldım ve ahâlî beni $a^{\prime} y \hat{a} n$ idüb yedime hâkimden hüccet alıvirdiler deyü ba'de'l-yevm nass-1 fermân-1 hümâyûnıma muhâlif $a^{\prime} y a ̂ n l ı k$ iddi'âsı iden olur ise veyahud şurût-1 merkûme üzre izn ve icâzet-i sadr-1 a'zamî ile $\boldsymbol{a}^{\text {'yân }}$ olanlar dahî vâlî ve hâkime akçe virdik ve masraf itdik deyü 
defter-i tevzî́a a'yâniyye nâm u tâm ile kendü nefisleri içün akçe idhâl kasdında olurlar ise keyfiyyet derhâl der-'aliyyeme ahâlî-yi vilâyet taraflarından sıhhatî üzre mahzar birle 'arz ve iştikâ ve i'lâm olınmak ve bu vechile kendisünden veya âher tarîk ile sû'-i hâl ve haraketi tahkîk olınan a'yân makûlelerinin bi-lâ emân cezâ-yı sezâları tertîb ve icrâ olınmak ve $a^{\boldsymbol{c} y}$ ân nasbı mücerred himâyet-i ra'iyyet olub 'askerî tâ'ifesinin müdâhale idecekleri serdârlık misüllü umûr-1 'askerîyyeden olmamağla ber-muktezây1 şürût a'yân 'azl u nasbında 'askerî tâ'ifesi vechân mine'l-vücûh karışdırılmamak ve fuzûlî karışmak irâde ider olur ise ocaklarına ifâde ve derhâl ocakları ma'rifetiyle zecr ü men' ve memnû' olmayanların te'dîbân lâyıkaları icrâ olmak üzre nizâm-ı mezkûrın devâm ve bekâsı hâlâtına her mahalde ihtimâm ve mikdâr-1 zerre hilâfına cür'et ile ve 'aydât-1 mezkûreye mazhariyyetden ittikâ-yı tâm eyleyesiz ve siz ki a'yânlarsız hâlinizi ve a'mâlinizi fermân-1 hümâyûnumın mazmûn-1 ita'ât-makrûnına uydırıb zulümden ve zulme vesîle olmakdan tehâsî ve mücânebet iderek kazâlarınız ahâlîlerinin evâmir-i şerîfem mûceblerince üzerlerine edâsı lâzım gelen tekâlifi ve umûr-1 mühimmeyi kemâl-i hakkâniyyet ve nısfet üzre tahsîl ve idâre itdirüb ve tevzî husûsında dahî şürût-1 istikâmetle tesvîyeye dikkat idüb mesârif-i sahîha-yı mühimmeden mâ'adâ nefsiniz içün veyahud fukarâyı mü(v)ekkil ittihâz iden zâlimler içün vâlî-yi memlekete evâmir-i şerîfe ile tahsîs kılınandan mâ'adâ vâlîler ve sancâk mutasarrıfları içün defter akçesi nâmı ve nâm-ı âher ile kâdîlar ve nâ'ibler içün tevzî‘ defterine bir akçe bir habbe zamm idhâl olınmamasına mezîd ikdâm ve dikkat ve sizleri dinlemeyüb ve evâmir-i şâhâneme imtisâl itmeyüb fukarâdan bigayr-i hakk akçe almak ve tevzî̀ defterine mesârif-i sahîhadan mâ‘adâ akçe idhâlini cebr itmek misüllü evzâ'a cesâret idenleri der-'aliyyeme i'lâm itdirmege dikkat ve eger i'lâm i'tâsında tereddüd olınur ise kazâlarınızın müftî ve 'ulemâ ve vücûh kendü tahrîrâtınız ile hakîkât-ı keyfiyyeti oldığı gibice der-sa'âdetime bildirmege ihtimâm ve bu vechile vikâye-yi nizâm ve himâyet-i 'ibâd-ı melik-i 'allâma sa'yi mâ-lâ-kelâm eyleyesiz şöyle ki işbu tenbîhât-ı şâhânemin icrâsında kangı mahalde rehâvet ve muhâlefet oldığı bilinmek için her kazânın mesârif defterleri dikkat ü kat sicillâtdan ihrâc ve der'aliyyeme celb ve imrâr-1 nazâr-1 dikkat olınacağı ve hilâf-ı tenbîhe kangı kazânın defterinde mesârif-i gayr-i sahîha bulınır ise ol kazânın a $a^{\boldsymbol{c}}$ yân hakkında bi-lâ imhâl tertîb-i cezâdan gayri mu'amele olınmayacağı muhakkak olmağla ânâ göre hareket ve himâyet ü siyânet-i ahâlî ve re'âyâya ez-dil ü cân ikdâm ve gayret eylemeniz bâbında fermân-ı 'âlî-şânım sâdır olmışdır buyurdım ki hükm-i şerîfemle vusûl buldıkda bu bâbda vech- 
i meşrûh üzre şeref-yâfte-yi sudûr olan fermân-1 vâcibi'l-ittibâ' ve lâzımi'limtisâlimin mazmûn-ı itâ'at-makrûnıle 'amel ve hareket ve hilâfindan gâyeti'l-gâyete tehâşî ve mücânebet eyleyesiz şöyle bilesiz âlâmet-i şerîfe i'timâd kılasız tahrîren fî evâ'il-i cemâzi'l-evvel sene semân ve tis'în ve mi'e ve elf kad vusile ileynâ ve kuyyide fî $17 \mathrm{~L}$ (Şevvâl) 1198. 